\title{
Mensen met een roeping: een zegen of een zorg in de hulpverlening?
}

\author{
Coranne Steenkamp-Scheinhardt \& Gérard Näring*
}

\begin{abstract}
Mensen met een roeping ervaren hun werk als zinvol. Roeping leidt tot een verhoogde motivatie voor het werk en zou daardoor met minder emotionele uitputting kunnen samenhangen. Ook het gerelateerde begrip spiritualiteit zou negatief samenhangen met emotionele uitputting. Roeping zou ook de relatie tussen emotionele belasting en uitputting kunnen modereren.

Bij 235 medewerkers in de geestelijke gezondheidszorg werd dit onderzocht. Spiritualiteit overlapte slechts in geringe mate met roeping. Verder bleek er een positieve samenhang te zijn tussen emotionele belasting en emotionele uitputting en een negatieve samenhang tussen roeping en emotionele uitputting. Roeping verklaarde vier procent van de variantie in emotionele uitputting, maar modereerde de relatie tussen emotionele belasting en emotionele uitputting niet. Eén aspect van spiritualiteit, verbondenheid met 'het zelf, hing ook negatief samen met emotionele uitputting. Mensen met een roeping zijn dus niet op een speciale manier beschermd tegen emotionele belasting, maar hebben wel minder last van emotionele uitputting.
\end{abstract}

\section{$1 \quad$ Inleiding}

Mensen verschillen in hun opvattingen over wat werk voor hen betekent en wat zij met hun werk voor anderen willen betekenen. Sommige mensen ervaren een roeping voor hulpverlenende beroepen. De keuze voor zo'n beroep is echter ook vaak een keuze voor emotioneel belastend werk waarvan bekend is dat het een verhoogd risico op burn-out met zich meebrengt. Het is tot nu toe niet onderzocht of een roeping in zo'n geval mensen minder kwetsbaar maakt voor uitputting.

\subsection{Persoonlijke betekenis van het werk}

Mensen verlenen persoonlijke betekenis aan hun werk op diverse gronden. Rosso, Dekas en Wrzesniewski (2010) brachten bronnen van betekenisverlening in kaart en stelden een driedeling voor: op grond van het zelf, op grond van anderen en op grond van de werkcontext. Het begrip het zelf is onmisbaar om betekenisverlening te begrijpen. Onder het zelf werd traditioneel het zelfconcept verstaan dat het totaal omvat van de gedachten en gevoelens die betrekking hebben op een persoon als object (Rosenberg, 1989). Het zelf wordt in de hedendaagse theorie opge-

* Coranne Steenkamp-Scheinhardt is werkzaam bij een landelijke ggz-instelling. E-mail: coranne.steenkamp@solcon.nl. Gérard Näring was ten tijde van dit onderzoek werkzaam bij de Open Universiteit. 
vat als een complexer construct, een werkend actief zelf, dat bestaat uit een set van actieve doelen en daaraan gekoppelde zelfbeelden (Conway, 2005). In zo'n werkend actief zelf is er een voortdurende constructie van doelen en betekenissen.

Studies naar betekenisverlening op grond van het zelf benaderen dit vanuit een aantal nauw aan elkaar gerelateerde perspectieven. Zo kan de nadruk vooral liggen op iemands waarden, men kan ook meer ingaan op wat voor opvattingen mensen hebben over de rol van het werk in hun leven, en tenslotte is een belangrijke invalshoek wat de motivatie is voor een baan (Rosso et al., 2010).

Hackman en Oldham (1976) verrichtten lang geleden al baanbrekend werk op het terrein van intrinsieke motivatie. Zij introduceerden de ervaren zinvolheid van het werk als een kernconcept en maakten duidelijk dat betekenis en intrinsieke motivatie nauw verbonden zijn. Anderen legden de nadruk op de betekenisverlening op grond van opvattingen over het werk en dit resulteerde in een indeling in mensen die hun werk zien als baan, als carrière of als roeping. Werknemers die hun werk zien als een baan, gebruiken de inkomsten uit het werk om doelen buiten het werk na te kunnen streven. Werknemers die hun werk als carrière ervaren, streven niet alleen naar een financiële beloning, maar ook naar vooruitgang binnen het werkveld om sociale redenen. Mensen die hun werk als roeping ervaren, werken niet voor de financiële beloning of voor een promotie, maar putten een intrinsieke motivatie uit het werkdomein zelf (Kamin \& Brinkman, 2008; Wrzesniewski, McCauley, Rozin \& Schwartz 1997).

\subsection{Roeping en zingeving}

Het construct roeping wordt beschreven in zowel een religieuze (Davidson \& Caddell, 1994) als seculiere context (Dobrow \& Tosti-Kharas, 2011; Wrzesniewski et al., 1997). In een religieuze context wordt roeping gezien als een uitnodiging van God of van een andere hogere macht aan het individu om een bepaald levensdoel te ontdekken en na te volgen. In een seculiere context wordt roeping onderzocht als een individuele, subjectieve ervaring. Iemand met zo'n soort roeping zoekt werk dat niet alleen in de eigen behoeften voorziet maar ook nuttig is voor het algemeen belang. Mensen met een roeping zijn idealisten, mensen met een prosociale motivatie (Duffy \& Dik, 2013). Mensen met een roeping voor hun werk ervaren, onafhankelijk van hun persoonskenmerken, ethische waarden die zij in een baan willen nastreven (Dobrow \& Tosti-Kharas, 2011). Het werk wordt gezien als zingevend en wordt uitgevoerd vanuit een sterke innerlijke overtuiging dat het bijdraagt aan een betere wereld (Bunderson \& Thompson, 2009; Hall \& Chandler, 2005; Thompson \& Bunderson, 2003; Weiss, Skelley, Haughey \& Hall, 2004). Roeping wordt vaak in verband gebracht met spiritualiteit, maar overlapt daar slechts gedeeltelijk mee.

\subsection{Spiritualiteit}

Mensen hebben het vermogen om orde te scheppen in een veranderende werkomgeving, om werkervaring en zelfbeeld te integreren. Spiritualiteit speelt daarbij een betekenis verlenende rol (Ashmos \& Duchon, 2000; Karakas, 2009; LipsWiersma, 2002; May, Gilson \& Harter, 2004; Weiss et al., 2004). Het is een con- 
cept dat niet refereert aan werk, maar vaak wel aan religie. In het geseculariseerde West-Europa geloven veel mensen dan wel niet in God, maar velen zijn wel geïnteresseerd in spiritualiteit.

In Nederland is het onderzoek naar spiritualiteit vooral gekoppeld aan gezondheidspsychologisch onderzoek. Onderzoekers van het Helen Dowling Instituut zien spiritualiteit als 'het streven naar en de ervaring van verbondenheid met de essentie van het leven', een universeel menselijk fenomeen, dat een rol kan spelen ongeacht religieuze of culturele achtergrond (De Jager Meezenbroek, Van der Berg, Tuytel, Visser \& Garssen, 2006). Spiritualiteit brengt in kaart hoe mensen zich op hun leven oriënteren en omvat verbondenheid met het zelf, verbondenheid met de omgeving, waaronder zorg voor anderen wordt begrepen, en verbondenheid met het transcendente. Er is duidelijk overlap met het aspect zingeving van roeping, maar spiritualiteit is breder, omdat het niet alleen werkgerelateerd is. Het bestrijkt het leven in zijn geheel. Mensen vinden spiritualiteit soms juist buiten hun werk. Verder ontbreekt het aspect van het gevoel hebben dat men voorbestemd of geroepen is om een bepaald soort werk te doen. Dat gevoel ergens toe bestemd te zijn verleent daarmee ook automatisch zingeving en bij spiritualiteit zoeken mensen dat juist. Hoewel diverse studies theoretisch onderbouwen dat er een samenhang zal zijn tussen het hebben van een roeping en het hebben van spirituele ervaringen, ontbreken daadwerkelijke cijfers hierover (Hirsbrunner, Loeffler \& Rompf, 2012). Een eerste doel van onze studie is om een schatting van de sterkte van het verband te geven. We verwachten dat deze begrippen slechts gedeeltelijk overlappen.

\subsection{Roeping en betrokkenheid bij het werk}

Mensen met een grote betrokkenheid bij hun werk ervaren, net als mensen met een roeping, hun werk als betekenisvol en centraal in hun leven (Dobrow \& TostiKharas, 2011). Maar roeping gaat nog een stap verder en omvat een passie voor een bepaald domein dat de baan overstijgt. Dobrow (2009) ziet roeping dan ook als basisoriëntatie in het leven omdat het tijdskader van ervaren roeping niet afgebakend wordt door een bepaalde baan maar een (levens)lange carrière omvat. Constructen als betrokkenheid en bevlogenheid zijn dus van roeping te onderscheiden door het kenmerk passie, door het langdurige tijdsaspect, en door de prosociale motivatie, maar er is ook een onderscheid te maken aan de hand van de relatie van het werk met het zelf of met identiteit. Waar bij bevlogenheid het werk belangrijk is voor de identiteit, valt werk bij mensen met een roeping samen met de identiteit (Dobrow, 2004). Mensen met een roeping definiëren zichzelf in eerste instantie via hun werk en kunnen zich niet voorstellen dat er ooit een tijd komt waarin zij dit werk niet meer zouden doen.

Mensen met een roeping werken in zeer verschillende domeinen zoals in het onderwijs, de geestelijkheid, de muziek, de kunst, management, de zorg of de geneeskunde (Dobrow \& Tosti-Kharas, 2011; Wrzesniewski, 2002). Met name de zorg was in veel landen tot in de jaren vijftig vrijwel exclusief in handen van religieuzen bij wie een roeping verondersteld werd. Nog steeds rapporteren veel verpleegkundigen dat zij vanuit een roeping in de zorg zijn gaan werken (Eley, Eley, Bertello \& Rogers-Clarck, 2012). In een studie in Israël bleken ook psychiaters, 
sociaal werkers en psychologen overwegend aan te geven dat zij vanuit een roeping werken (Baruch, Swartz, Sirkis, Mirecki \& Barak, 2013). Dit zijn beroepen die als zwaar bekend staan en waarin in de jaren zeventig voor het eerst een klachtensyndroom werd waargenomen dat burn-out werd genoemd (Maslach, Schaufeli \& Leiter, 2001).

\subsection{Emotionele belasting, emotionele uitputting en emotionele hulpbronnen}

Werken in de zorg kan voldoening geven, maar het is ook werk met een hoge emotionele belasting (Ybema \& Smulders, 2002). Emotionele belasting verwijst naar de mate waarin mensen in situaties werken die een sterke emotionele impact hebben. Die situaties worden gekenmerkt door emotionele, problematische of bedreigende contacten met patiënten (Ybema \& Smulders, 2002). Langdurig werken in zo'n omgeving kan leiden tot burn-out, een complex van drie symptomen: emotionele uitputting, depersonalisatie en een verminderd gevoel van persoonlijke bekwaamheid. Emotionele uitputting wordt hierin als kernaspect gezien en effecten van dit aspect van burn-out zijn in deze studie onderzocht. Onder de kenmerken van het werk die van invloed zijn op het ontstaan van emotionele belasting en uitputting, vinden we taakeisen maar ook hulpbronnen (Bakker \& Demerouti, 2006; Näring, Vlerick \& Van de Ven, 2012). Het Job DemandsResources (JD-R) model is een veelgebruikt model dat een goed theoretisch kader biedt om de gevolgen van zowel taakeisen als hulpbronnen op het welzijn van werknemers te verklaren. Het model veronderstelt een positief lineair verband tussen hoge taakeisen en uitputting. In overeenstemming met bevindingen in vele eerdere studies formuleren we de eerste hypothese:

\section{- Hypothese 1:}

Emotionele belasting vertoont een positieve relatie met emotionele uitputting.

In het JD-R model kan allereerst een direct verband tussen roeping en uitputting worden verondersteld. De sterke ervaring van zinvolheid van het werk zal samenhangen met een hoge intrinsieke motivatie. Omdat energie en motivatie in het JD-R model onlosmakelijk aan elkaar verbonden zijn (Van den Broeck, 2013), zal een sterke roeping het motivatieproces versterken. De hulpbronnen voorkomen dan rechtstreeks emotionele uitputting.

\section{- Hypothese 2:}

Roeping heeft een negatieve relatie met emotionele uitputting.

Daarnaast veronderstelt het model dat hulpbronnen ook het effect van werkkenmerken op stressreacties modereren (Schaufeli \& Taris, 2013). Naast werkgerelateerde hulpbronnen kunnen ook individuele kenmerken van de werknemer als hulpbron fungeren. Roeping is bij uitstek zo'n kenmerk en kan in het JD-R model (Demerouti, Bakker, Nachreiner \& Schaufeli, 2001) als een moderator worden gezien; er is dan sprake van stress-buffering (Schaufeli \& Taris, 2013). 
- Hypothese 3:

Roeping modereert de relatie tussen emotionele belasting en emotionele uitputting. De relatie tussen emotionele belasting en emotionele uitputting is bij respondenten met een hoge score op roeping zwakker dan bij respondenten die laag scoren op roeping.

\subsection{Spiritualiteit en emotionele uitputting}

Ook tussen spiritualiteit en burn-out kan op basis van twee gronden een negatief verband worden verondersteld. Allereerst is opgemerkt dat het experiëntiële aspect van spiritualiteit, het werken vanuit een innerlijke rust, een directe en natuurlijke tegenhanger is van stress (Holland \& Neimeyer, 2005). Dat zou wijzen op een direct negatief verband tussen spiritualiteit en burn-out. De meeste studies naar de relatie tussen spiritualiteit en aspecten van burn-out betreffen geestelijken en in die beroepsgroep bleek spiritualiteit $2 \%$ van de variantie in burn-out te verklaren, ook na controle voor persoonskenmerken en werkkenmerken (Golden, Piedmont, Ciarrocchi \& Rodgerson, 2004). We verwachten in de huidige studie een soortgelijk verband.

- Hypothese 4:

Spiritualiteit heeft een negatieve relatie met emotionele uitputting.

Spiritualiteit wordt echter vooral genoemd als een cognitieve copingstrategie die bij uitstek behulpzaam is om betekenis te geven aan moeilijke situaties zoals het omgaan met lijden en sterven. Dit aspect van spiritualiteit zou wijzen op een modererende rol, die overigens in de zojuist genoemde studies niet verondersteld en niet gerapporteerd werd.

- Hypothese 5:

Spiritualiteit modereert de relatie tussen emotionele belasting en emotionele uitputting. De relatie tussen emotionele belasting en emotionele uitputting is bij respondenten met een hoge score op spiritualiteit zwakker dan bij respondenten die laag scoren op spiritualiteit.

\section{Methode}

\subsection{Respondenten en procedure}

De steekproef voor dit onderzoek werd met instemming van het management en met hulp van de afdelingen ICT en Media getrokken uit de 699 medewerkers met een e-mailadres bij een landelijke ggz-instelling met een duidelijke religieuze identiteit. De medewerkers waren werkzaam op diverse afdelingen op diverse vestigingen in Nederland, zowel in de zorg als op ondersteunende afdelingen. Na een vooraankondiging van het onderzoek via intranet kregen de medewerkers via hun e-mailadres van de werkplek een link met code naar een anoniem digitaal in te vullen vragenlijst toegestuurd. Het invullen was alleen mogelijk vanaf een computer op de werkplek. Onder de inzenders werden vier boekenbonnen van $€ 25$ ver- 
loot. Dit leverde na drie weken een respons op van 275 ingevulde enquêtes, waaronder 235 volledig ingevuld (netto-respons 34\%).

De groep respondenten blijkt redelijk representatief voor de totale populatie. Van de medewerkers bij de instelling is $62 \%$ vrouw en $38 \%$ man. Dit is vergelijkbaar met de verdeling onder de respondenten: $60 \%$ vrouw en $40 \%$ man. De verdeling naar leeftijd laat zien dat de grootste groep medewerkers, $36 \%$, een leeftijd heeft in de range van 25-34 jaar. De grootste leeftijdsgroep respondenten, met $28 \%$, is 30-39 jaar. 57\% van alle medewerkers werkte één tot vijf jaar bij de instelling, terwijl van de respondenten $44 \%$ één tot vijf jaar bij de instelling werkte. Het aandeel medewerkers en respondenten dat vijf à tien jaar bij de instelling werkt, was vergelijkbaar: $19 \%$ van de medewerkers en $20 \%$ van de respondenten.

Van de respondenten had $63 \%$ een afgeronde hbo- of wo-opleiding, $26 \%$ een mbo-opleiding en $11 \%$ alleen een middelbareschooldiploma. $40 \%$ van de respondenten werkt 33 tot 40 uur per week, 20\% 25 tot 32 uur. $8 \%$ van de respondenten werkt meer dan 40 uur per week. Deze laatste gegevens konden voor de totale groep medewerkers van deze instelling op dit moment niet worden achterhaald.

\subsection{Meetinstrumenten}

De vragenlijst bestond uit 60 items, verdeeld over de schalen roeping (12 vragen), spiritualiteit ( 26 vragen), emotionele belasting (7 vragen) en emotionele uitputting (8 vragen), en zeven vragen naar enkele achtergrondvariabelen. Alle schalen voldeden aan het criterium voor een goede interne consistentie (Field, 2005), een waarde van Cronbach's $\alpha$ van ongeveer .80 .

\section{- Emotionele belasting}

Emotionele belasting is gemeten met de zeven items van de VBBA-schaal 'emotionele belasting' (Van Veldhoven \& Meijman, 1994). De Vragenlijst Beleving en Beoordeling van de Arbeid (VBBA) is een Nederlandse werkbelevingsvragenlijst die 16 werkkenmerken meet. De schaal 'emotionele belasting' meet de mate van werkbelasting als gevolg van contactuele taakeisen waaronder agressie en geweld, en cliënt- en patiëntgedrag. Voorbeeld van een item: 'Is uw werk emotioneel zwaar?' De items werden gescoord op een 4-punts Likertschaal variërend van altijd (1) tot nooit (4) en gemiddeld tot een schaal voor emotionele belasting. De antwoorden werden gehercodeerd zodat de scores dezelfde betekenis kregen als de scores op de andere variabelen: hoe hoger de score, hoe sterker het te meten construct ervaren werd. De betrouwbaarheid van de schaal was redelijk/goed: Cronbach's $\alpha$ voor de schaal emotionele belasting was .79.

\section{- Emotionele uitputting}

Emotionele uitputting is gemeten met de acht items van de gelijknamige schaal van de Utrechtse Burn-out Schaal voor contactuele beroepen (UBOS-C). De UBOS is de Nederlandse versie van de Maslach Burnout Inventory. Het is een individueel af te nemen vragenlijst die een werkgerelateerde psychische vermoeidheidstoestand kwantificeert (Schaufeli \& Van Dierendonck, 2000). Voorbeeld van een item: 'Aan het einde van een werkdag voel ik mij leeg.' De items worden gescoord op een 7-punts Likertschaal met antwoorden variërend van 'nooit' (0) tot 'dage- 
Tabel 1 Nederlandse vertaling van de Dobrow Calling Scale; in het onderzoek zijn de items $4 \mathrm{t} / \mathrm{m} 12$ gebruikt

\begin{tabular}{|c|c|}
\hline I. & Ik ben erg enthousiast over mijn werk voor/met deze doelgroep. \\
\hline 2. & Ik geniet van mijn werk voor/met deze doelgroep. \\
\hline 3. & Werken voor/met deze doelgroep geeft mij persoonlijk enorm veel voldoening. \\
\hline 4. & Ik zou alles opofferen om voor/met deze doelgroep te kunnen werken. \\
\hline 5. & $\begin{array}{l}\text { Het eerste wat vaak in mij opkomt wanneer ik anderen iets over mijzelf vertel is het } \\
\text { werk dat ik doe voor/met deze doelgroep. }\end{array}$ \\
\hline 6. & Zelfs bij flinke tegenslagen zou ik blijven werken voor/met deze doelgroep. \\
\hline 7. & $\begin{array}{l}\text { Ik weet dat het werk voor/met deze doelgroep - professioneel of als vrijwilliger - } \\
\text { altijd een deel van mijn leven zal zijn. }\end{array}$ \\
\hline 8. & Ik heb een gevoel dat het voorbestemd is dat ik voor/met deze doelgroep werk. \\
\hline 9. & Mijn werk voor/met deze doelgroep speelt in mijn gedachten altijd een rol. \\
\hline 10. & Zelfs wanneer ik niet werk denk ik vaak na over deze doelgroep. \\
\hline $1 \mathrm{I}$. & Mijn bestaan zou minder zin hebben zonder mijn betrokkenheid bij deze doelgroep. \\
\hline 12. & $\begin{array}{l}\text { Mijn werk voor/met deze doelgroep is een zeer inspirerende en bevredigende erva- } \\
\text { ring voor mij. }\end{array}$ \\
\hline
\end{tabular}

NB: Waar hier het zinsdeel 'deze doelgroep' is gebruikt, kunnen domein-specifieke kenmerken van onderzoek worden ingevuld.

lijks/altijd' (6) en gemiddeld tot een schaal voor emotionele uitputting. De betrouwbaarheid van deze schaal is goed, Cronbach's $\alpha=.87$.

- Roeping

Om roeping te operationaliseren werd gebruikgemaakt van de 12 items van de Dobrow Calling Scale (Dobrow \& Tosti-Kharas, 2011). Deze schaal meet in hoeverre respondenten een diepe innerlijke betekenisverlening ervaren bij hun werk en het als roeping ervaren. De items zijn zodanig geformuleerd dat zij kunnen worden aangepast aan het te onderzoeken werkdomein. De schaal werd in het Nederlands vertaald. Voorbeeld van een item is: 'Werken voor deze doelgroep geeft mij persoonlijk veel voldoening.' De antwoorden worden gemeten met 7-punts schalen van (1) 'helemaal mee oneens' tot (7) 'helemaal mee eens' en de items worden gemiddeld tot één score voor roeping. In de uitwerking van de resultaten van het onderzoek is een verkorte schaal van 9 items gebruikt. Cronbach's $\alpha$ van deze verkorte roepingschaal is .85. Cronbach's $\alpha$ van de roepingschaal zoals beschreven door Dobrow en Tosti-Kharas (2011) was .90 en .94 voor twee cross-sectionele afname-samples (zie tabel 1 voor de items).

\section{- Spiritualiteit}

Spiritualiteit is gemeten met de Spirituele Attitude en Interesse Lijst (SAIL). De SAIL brengt de spirituele attitude van volwassen respondenten in kaart. Deze attitude wordt als religie-overstijgend beschouwd. Daarbij worden 'verbondenheid met het zelf' (opgebouwd uit de subschalen 'zingeving', 'vertrouwen' en 'aan- 
vaarding'), verbondenheid met de omgeving (opgebouwd uit de subschalen 'zorg om anderen' en 'verbondenheid met de natuur') en verbondenheid met het transcendente (opgebouwd uit de subschalen 'transcendente ervaringen' en 'spirituele activiteiten') als kernelementen beschouwd (De Jager Meezenbroek, Garssen, Van der Berg, Van Dierendonck, Visser \& Schaufeli, 2012a; De Jager Meezenbroek, Garssen, Van der Berg, Tuytel, Van Dierendonck, Visser \& Schaufeli, 2012b). In deze studie wordt uitgegaan van de drie kernelementen. Voorbeeld van een item om 'verbondenheid met het zelf te meten is: 'In moeilijke tijden bewaar ik mijn innerlijke rust.' Voorbeeld van een item voor 'verbondenheid met de omgeving' is: 'Ik probeer in mijn leven wat voor de maatschappij te betekenen.' Een voorbeeld van een item van de subdimensie 'verbondenheid met het transcendente' is: 'Er is een God of een hogere macht in mijn leven die mij richting geeft'. De SAIL bestaat uit 26 items die worden gescoord op een 6-punts Likertschaal met antwoordmogelijkheden variërend van 'helemaal niet' (1) tot 'in zeer hoge mate' (6). De itemscores werden totaal voor spiritualiteit en voor elk van de drie kernelementen gemiddeld. De betrouwbaarheid van deze schalen was redelijk tot goed. Cronbach's $\alpha=.87$ voor de volledige lijst $(M=4.43, S D=0.43)$. Voor de schaal 'verbondenheid met jezelf' (11 items) Cronbach's $\alpha=.82(M=4.57, S D=0.46)$, voor 'verbondenheid met de omgeving' (6 items) Cronbach's $\alpha=.74(M=4.77, S D$ $=0.52$ ) en voor 'verbondenheid met het transcendente' (9 items) Cronbach's $\alpha$ $=.80(M=4.04, S D=0.68)$.

\section{- Sociaal-demografische variabelen}

Er werden vijf sociaal-demografische kenmerken opgenomen: sekse, lengte van het dienstverband, leeftijdscategorie, opleidingsniveau en aantal werkuren per week. Voor de lengte van het dienstverband is respondenten gevraagd hoelang zij al werkzaam zijn voor de instelling: (1) minder dan een jaar, (2) 1 à 2 jaar, (3) 2 à 5 jaar, (4) 5 à 10 jaar, (5) 10 à 20 jaar, (6) meer dan 20 jaar. Voor leeftijdscategorie is gevraagd aan te geven tot welke van zes leeftijdscategorieën men behoorde: (1) jonger dan 20 jaar, (2) 20-29 jaar, (3) 30-39 jaar, (4) 40-49 jaar, (5) 50-59 jaar en (6) 60 jaar en ouder. Voor opleidingsniveau is gevraagd naar de hoogst afgeronde opleiding: (1) vmbo/lbo, (2) mavo, (3) havo, (4) vwo, (5) mbo, (6) hbo, (7) wo. Voor het aantal uren werk per week is gevraagd één van zes mogelijkheden aan te vinken: (1) 8 uur per week of minder, (2) 9-16 uur per week, (3) 17-24 uur per week, (4) 25-32 uur per week, (5) 33-40 uur per week, of (6) meer dan 40 uur per week.

\subsection{Statistische analyse}

Voorafgaand aan de analyse waren variabelen waar nodig gehercodeerd zodat alle scores op de te onderzoeken constructen dezelfde betekenis kregen: hoe hoger de score, hoe sterker het te meten construct ervaren werd. Alle predictoren in de regressieanalyses werden gecentreerd.

Aangezien de roepingschaal voor deze studie uit het Engels is vertaald en voor het eerst in Nederland werd gebruikt, is de factorstructuur bepaald. Daartoe werd een confirmatieve factoranalyse (CFA) uitgevoerd met LISREL 8.80 (Jöreskog \& Sörbom, 1996). De factormodellen werden geëvalueerd middels de Chi-kwadraat, 
de comparative fit index (CFI), de Bentler-Bonnet non-normed fit index (NNFI) en de root mean square error of approximation (RMSEA). Voor de CFI en NNFI zijn waarden > .90 een indicatie dat het model acceptabel is (Bentler \& Bonnet, 1980). Waarden van de RMSEA kleiner dan of gelijk aan .08 wijzen op een acceptabele fit van het model (Hu \& Bentler, 1999).

Voor het toetsen van de hypotheses werden eerst correlaties berekend (Pearson's $r$ ). Daarna werd een hiërarchische regressieanalyse uitgevoerd. De controlevariabelen die significant correleerden met emotionele uitputting, werden in een aparte stap als eerste in het regressiemodel opgenomen.

\section{Resultaten}

\subsection{Beschrijvende statistieken}

- Emotionele belasting en emotionele uitputting

De gemiddelde score voor emotionele belasting in deze groep medewerkers, $M=$ $2.25, S D=.42$, is vergelijkbaar met andere gegevens van medewerkers in de gezondheids- en welzijnszorg, $M=2.09$ (Van den Bossche, Hupkens, De Ree \& Smulders, 2006). De deelnemers geven dus aan dat zij dit gemiddeld iets vaker dan 'soms' meemaken.

De gemiddelde score voor emotionele uitputting bij medewerkers bij deze instelling, $M=1.38, S D=.85$, ligt lager dan de gemiddelde score gerapporteerd in de normtabel van de UBOS- $C$ voor gezonde medewerkers in de gezondheidszorg, $M$ $=1.78, S D=.99$, en ook lager dan de score voor therapeutisch personeel in de geestelijke gezondheidszorg, $M=1.96, S D=1.12$. De drie scores kunnen echter allemaal als 'gemiddeld' worden geclassificeerd (Schaufeli \& Van Dierendonck, 2000).

\section{- $\quad$ Roeping en spiritualiteit}

De eerste drie items van de vertaalde roepingschaal waren vanwege uitsluitend hoge scores erg scheef verdeeld, en om die reden zijn deze items uit de analyse gehouden. Met weglating van deze drie items bleek een goede eendimensionale schaal te construeren. Het resulterende factormodel met 9 items liet een goede fit zien (Chi-kwadraat $=51.60, d f=25, p=.001, \mathrm{CFI}=.98$, NNFI $=.97$, RMSEA $=.06$ ), met een goede betrouwbaarheid voor de resulterende schaal, Cronbach's $\alpha$ $=.86, n=235$. In het model werden gecorreleerde errortermen toegestaan voor de items 9 en 10 en voor de items 6 en 12. De drie weggelaten items vragen naar enthousiasme over het werk (1), genieten van het werk (2), en voldoening in het werk (3). Het zijn vragen die inhoudelijk gezien gaan over plezier en intrinsieke motivatie en ze zijn daarmee blijkbaar niet specifiek voor roeping.

De gemiddelde score voor roeping onder respondenten was $M=4.60, S D=.98$. Dat is iets hoger dan de score voor roeping zoals gemeten door Dobrow en TostiKharas (2011) in de cross-sectionele samples management, $M=4.40, S D=1.28$, en business, $M=4.21, S D=.99$. De gemiddelde gemeten score voor spiritualiteit 
bij deze groep respondenten was 4.43. Dit is vergelijkbaar met de algemene groep 'gezonde volwassenen' (De Jager Meezenbroek et al., 2006).

\subsection{Verband tussen roeping en functie en tussen roeping en leeftijd}

Naarmate de deelnemers aan onze studie meer uren per week werken of een hogere opleiding hebben voltooid, ervaren zij meer emotionele uitputting.

\subsection{Verbanden tussen roeping en spiritualiteit en emotionele uitputting}

Er is een significant verband tussen roeping en spiritualiteit, $r=.34, p<.01$. Het zijn dus volgens het criterium van Cohen (1988) matig aan elkaar gerelateerde constructen. De samenhang van roeping met elk van de drie subschalen voor spiritualiteit is ongeveer even sterk en ook significant: 'verbondenheid met het zelf', $r=.24$, 'verbondenheid met de omgeving', $r=.28$, en 'verbondenheid met het transcendente', $r=.29$, in alle gevallen $p<.01$. Een tweede indicatie voor het verschil tussen de constructen vinden we door de correlaties van de concepten met emotionele uitputting in tabel 2 te vergelijken.

Tussen roeping en emotionele uitputting bestaat een significante, zwak negatieve samenhang, $r=-.19, p<.01$. De samenhang tussen spiritualiteit en emotionele uitputting is niet significant, $r=-.06, n s$. Van de drie subschalen voor spiritualiteit vertoont 'verbondenheid met het zelf' een zwak negatieve significante samenhang met emotionele uitputting, $r=-.22, p<.01$. 'Verbondenheid met de omgeving', $r=.02$, ns, en 'verbondenheid met het transcendente', $r=.06, n s$, hangen niet samen met emotionele uitputting.

\subsection{Regressieanalyse: roeping en spiritualiteit als predictoren en als moderatoren}

In tabel 3 zijn de resultaten van de hiërarchische regressieanalyse weergegeven. Allereerst zijn in stap 1 de achtergrondvariabelen ingevoerd. Leeftijd, opleidingsniveau, en uren werk per week verklaren gezamenlijk $7 \%$ van de variantie in emotionele uitputting, $\Delta R^{2}=.07, F(3,231)=7.26, p<.001$.

Emotionele belasting werd in stap 2 ingevoerd en verklaarde een aanvullende $7 \%$ van de variantie in emotionele uitputting, $F(1,230)=17.77, p<.001$. Hoe meer emotionele belasting ervaren wordt, hoe sterker de emotionele uitputting. Dit is conform verwachtingen (Schaufeli \& Van Dierendonck, 2000) en bevestigt hypothese 1 . Het toevoegen van ervaren roeping voor het werk in stap 3 leidde opnieuw tot een toename van $4 \%$ in verklaarde variantie in emotionele uitputting, $F(1,229)=11.62, p=.001$. Roeping heeft een direct verband met emotionele uitputting. Een sterkere roeping voor het werk hangt significant samen met lagere emotionele uitputting (hypothese 2). In stap 4 werd spiritualiteit toegevoegd, maar dit verklaarde niet significant meer variantie in emotionele belasting, $\Delta R^{2}=.01, F(1,228)=2.56$, ns. In stap 5 werd de interactie van emotionele belasting en roeping ingevoerd, in stap 6 de interactie van emotionele belasting en spiritualiteit. Noch roeping, noch spiritualiteit bleek het verband tussen emotionele belasting en emotionele uitputting te modereren. 


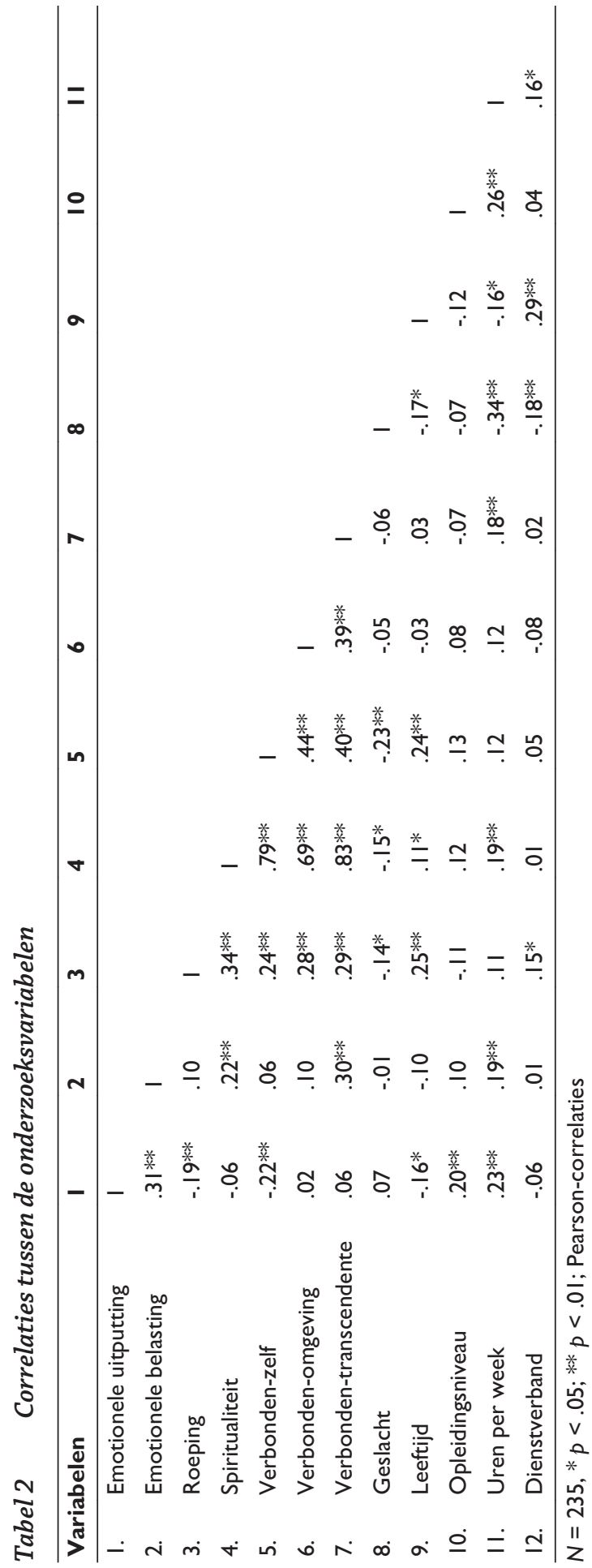


Tabel 3 Hiërarchische regressieanalyse met als criterium emotionele uitputting en als predictoren emotionele belasting, roeping en spiritualiteit

\begin{tabular}{|c|c|c|c|c|c|c|}
\hline \multicolumn{7}{|l|}{ Emotionele uitputting } \\
\hline & Stap I & Stap 2 & Stap 3 & Stap 4 & Stap 5 & Stap 6 \\
\hline \multicolumn{7}{|l|}{ Controlevariabelen } \\
\hline Opleidingsniveau & $.14 *$ & $.13 *$ & .10 & .11 & .11 & .11 \\
\hline Leeftijdscat. & -.11 & -.09 & -.04 & -.03 & -.03 & -.03 \\
\hline Uren werk & $.17 * *$ & $.13 *$ & $.16 * *$ & $.18 * *$ & $.18 * *$ & $.18 * *$ \\
\hline Emotionele belasting & & $.26 * *$ & $.28 * *$ & $.30 * *$ & $.30 * *$ & $.30 * *$ \\
\hline Roeping & & & $-.21 * *$ & $-.18 * *$ & $-.18^{* *}$ & $-.18 * *$ \\
\hline Spiritualiteit & & & & -.11 & -.11 & -.11 \\
\hline $\begin{array}{l}\text { Emotionele belasting } x \\
\text { Roeping }\end{array}$ & & & & & -.02 & -.02 \\
\hline $\begin{array}{l}\text { Emotionele belasting } x \\
\text { Spiritualiteit }\end{array}$ & & & & & & .01 \\
\hline Adjusted $R^{2}$ & .07 & .14 & .18 & .18 & .18 & .18 \\
\hline$R^{2}$ & .09 & .15 & .19 & .20 & .20 & .20 \\
\hline$\Delta R^{2}$ & $.09 * *$ & $.07 * *$ & $.04 * *$ & .01 & .01 & .01 \\
\hline
\end{tabular}

$* p<0.05 ; * * p<0.01$

De aangegeven waarden zijn gestandaardiseerde regressiecoëfficiënten $(\beta)$.

\section{Discussie}

Bij een steekproef van de werknemers van een ggz-instelling in Nederland werd onderzocht in hoeverre ervaren roeping voor het werk het verband tussen emotionele belasting en emotionele uitputting modereert. In dit onderzoek werd een direct verband tussen roeping en emotionele uitputting gevonden, maar roeping modereerde het verband tussen emotionele belasting en emotionele uitputting niet.

In overeenstemming met eerder onderzoek (Schaufeli \& Van Dierendonck, 2001) bestaat er ook bij deze groep respondenten een significant verband tussen emotionele belasting en emotionele uitputting. Hypothese 1 werd hiermee bevestigd. Uit het onderzoek bleek tevens dat naarmate mensen hun werk sterker als roeping ervaren, zij lager scoren op emotionele uitputting (hypothese 2). Het verband tussen roeping en emotionele uitputting was wat minder sterk dan het effect van emotionele belasting op emotionele uitputting, $4 \%$ versus $7 \%$. De mate van emotionele uitputting was volgens de cijfers van de normtabel gemiddeld.

\subsection{Roeping en spiritualiteit}

In het onderzoek werd eerst nagegaan in hoeverre spiritualiteit en roeping overlappende begrippen zijn. Een matige correlatie vormde een indicatie voor ver- 
schillende constructen. Ook bleek roeping significant negatief samen te hangen met emotionele uitputting, maar dit gold niet voor spiritualiteit. Wel hing één aspect van spiritualiteit, verbondenheid met het zelf, ook negatief samen met emotionele uitputting. 'Verbondenheid met het zelf' wordt uitgedrukt in aspecten als authenticiteit, innerlijke harmonie, innerlijke vrede, bewustzijn, zelfkennis en het ervaren van een zoektocht naar betekenis in het leven (De Jager Meezenbroek et al., 2012a; 2012b). Juist dit aspect van spiritualiteit lijkt een persoonlijke hulpbron te zijn bij onze onderzoeksgroep. Werk kan een rol spelen bij het zoeken naar spiritualiteit, maar mensen kunnen hun werk ook als baan of carrière zien, en tegelijkertijd spiritualiteit zoeken buiten hun werk. Voor mensen met een roeping is de zin van het leven juist in het werk te vinden en valt het werk samen met het zelf (Dobrow, 2004).

\subsection{Roeping en emotionele uitputting}

Een van de aannames van het JD-R model is dat werkeisen en hulpbronnen kunnen interacteren en zo tot meer of minder uitputting kunnen leiden. Het model beschrijft een motivatieproces waarbij de aanwezigheid van hulpbronnen via positieve emoties leidt tot bevlogenheid en betrokkenheid bij de organisatie (Bakker \& Demerouti, 2006; Demerouti et al., 2001; Schaufeli \& Van Rhenen, 2006; Van Ruysseveldt, 2006). Een subjectief kenmerk van medewerkers, zoals de manier waarop ze in hun werk staan, lijkt van invloed op versterking van het motivatieproces in het Job-Demands Resources model.

Een grote studie onder een dwarsdoorsnede van de Nederlandse bevolking rapporteerde een minieme rol voor rechtstreeks gemeten intrinsieke motivatie bij het verklaren van emotionele uitputting, een verklaarde variantie van 1\% (Van den Broeck, Van Ruysseveldt, Smulders \& De Witte, 2011). In de hier gerapporteerde studie bij mensen die in de ggz werkzaam zijn, was roeping sterk rechtstreeks gerelateerd aan emotionele uitputting. Dat toont aan dat voor het begrijpen van uitputtingsprocessen in deze beroepsgroep een concept van belang is.

Hypothese 3 werd niet bevestigd. De persoonlijke hulpbron die roeping blijkbaar is, biedt geen extra bescherming tegen een belastende werkomgeving. Ook deze werknemers hebben dus in moeilijke werkomstandigheden externe hulpbronnen nodig, zoals steun van collega's en steun van de leidinggevenden (Wood et al., 2011).

\subsection{Spiritualiteit en emotionele uitputting}

In onze studie vonden we een zwak direct negatief verband tussen spiritualiteit en emotionele uitputting, dat verklaard kan worden door de overlap van roeping met verbondenheid met het zelf die hiervoor al beschreven werd. Echter, het verband verdween zodra roeping ook als predictor aan het model werd toegevoegd. Recent bleek ook bij verpleegkundigen spiritualiteit een direct negatief verband te hebben met burn-out (Galea, 2014a). Terwijl roeping duidelijker geconceptualiseerd is als sturend, is spiritualiteit zowel op te vatten als richtinggevend, als iets waar mensen naar op zoek zijn, alsook als iets wat mensen hebben gerealiseerd, een toestand. In die laatste betekenis is spiritualiteit in werkgerelateerd onderzoek ook als resultante gezien. Stress bleek bijvoorbeeld schadelijk voor spirituele 
ervaringen op het werk (Galea, 2014b). Dezelfde visie spreekt ook uit een vroege omschrijving van burn-out als 'an erosion in values, dignity, spirit, and will, an erosion of the human soul' (Maslach \& Leiter, 1997, p. 17). Het lijkt ons ook zinvoller spiritualiteit in toekomstig onderzoek als uitkomstmaat te hanteren.

\subsection{Roeping en functie en roeping en leeftijd}

Psychologen en hbo-begeleiders en individueel behandelaars hebben frequent direct persoonlijke en direct langdurige sociale en emotionele interactie met de cliënten in deze instelling, kenmerken van het werk die leiden tot emotionele belasting (Maslach et al., 2001; Ybema \& Smulders, 2002).

Oudere medewerkers in deze instelling ervaren juist minder emotionele belasting dan jongere medewerkers. Er bestaat ook een positieve samenhang tussen leeftijd en roeping en tussen dienstverband en roeping. Deze verbanden kunnen erop wijzen dat het juist de ouderen zijn die, mogelijk juist door hun roeping, gedurende veel dienstjaren hun werkzaamheden hebben kunnen uitvoeren zonder emotioneel uitgeput te raken.

\subsection{Beperking van het onderzoek}

Omdat het onderzoeksdesign cross-sectioneel van aard is, kunnen uit de gevonden samenhangen geen conclusies met betrekking tot oorzakelijke verbanden getrokken worden. Verder is het onderzoek verricht onder een groep medewerkers met een enerzijds weliswaar zeer gevarieerde achtergrond wat betreft werkzaamheden die zij voor de instelling verrichten, anderzijds zijn zij allen werkzaam in een ggz-instelling met een duidelijke eigen religieuze identiteit.

\subsection{Suggesties voor verder onderzoek}

Een idee voor nader onderzoek kan zijn de relatie tussen roeping en bevlogenheid te onderzoeken. Bevlogenheid wordt beschreven als een positieve, affectiefcognitieve toestand van opperste voldoening die gekenmerkt wordt door vitaliteit, toewijding en absorptie (Bakker, Albrecht \& Leiter, 2011; Schaufeli \& Bakker, 2001). Deze toestand wordt door taak-specifieke hulpbronnen op het werk opgeroepen (Bakker \& Demerouti, 2006; Christian, Garza \& Slaughter, 2011) en kan dus ook fluctueren al naar gelang de ervoor benodigde hulpbronnen meer of minder aanwezig zijn (Sonnentag, 2011). Een vergelijking van deze definitie met die van roeping maakt duidelijk dat bevlogenheid samenhangt met werkaspecten terwijl roeping samenhangt met een werkattitude of motivatie vanuit een hoger doel. Zo is bevlogenheid gekoppeld aan een baan en meestal ook aan een werkgever (Sonnentag, 2011). Roeping daarentegen is niet alleen baan-overstijgend (Dobrow, 2009), maar ook werk-overstijgend. Werkende mensen met een roeping blijken vaak te rapporteren dat ze bevlogen zijn (Rothmann \& Hamukang'andu, 2013).

Omdat het construct roeping zo vaak automatisch in een religieuze of spirituele context gebruikt wordt, lijkt het zinvol de resultaten van onderzoek bij een ggzinstelling met religieuze signatuur te vergelijken met resultaten van onderzoek naar de roeping bij een ggz-instelling zonder expliciet religieuze signatuur. Daar- 
mee zou kunnen worden nagegaan of roeping, zoals gemeten met de hier gebruikte roepingschaal, inderdaad een seculier begrip is.

Een andere suggestie is specifiek onderzoek te verrichten naar expliciet negatieve uitkomsten van een roepingsmotivatie voor het werkveld, zoals tunnelvisie, een eenzijdige focus op het werk, te hoge zelf opgelegde werkbelasting en sterke gedrevenheid (Dobrow, 2004; Weiss et al., 2004).

Ook zou men kunnen trachten de effecten van de constructen werk als baan en werk als carrière te operationaliseren teneinde de effecten op emotionele uitputting te kunnen vergelijken met die van roeping.

\section{Conclusie}

De gegevens uit ons onderzoek bevestigen dat emotionele belasting een positieve relatie heeft met emotionele uitputting. Het blijkt dat een zelf ervaren roepingsmotivatie, waarbij mensen een diepe overtuiging hebben betekenisvol werk te doen dat bijdraagt aan een betere wereld, negatief samenhangt met emotionele uitputting. In deze studie werd ook een zwak direct negatief verband gevonden tussen spiritualiteit en emotionele uitputting, een verband dat echter verdween zodra roeping ook als predictor aan het model werd toegevoegd. Roeping en spiritualiteit modereren echter het verband tussen emotionele belasting en emotionele uitputting niet. De werknemers in dit onderzoek hadden gemiddeld een lagere score op emotionele uitputting dan vergelijkbare beroepsgroepen. Bovendien was deze score lager, naarmate zij meer roeping ervoeren. Mensen met een roeping vormen dus een bijzondere beroepsgroep.

\section{Praktijkbox}

Wat betekenen de resultaten van dit onderzoek voor de praktijk?

- In de hier gerapporteerde studie bij mensen die in de ggz werkzaam zijn, was roeping sterk rechtstreeks negatief gerelateerd aan emotionele uitputting. Dat toont aan dat voor het begrijpen van uitputtingsprocessen in deze beroepsgroep een concept van belang is. De manier waarop werknemers in hun werk staan, kan worden ingebracht in functioneringsgesprekken. Mensen die hun werk als roeping ervaren, putten een intrinsieke motivatie uit het werkdomein zelf. Hoe hoger mensen scoren op het ervaren van hun werk als roeping, hoe lager zij scoren op emotionele uitputting. Medewerkers kunnen doelgericht worden geholpen om beter zicht te krijgen op hun eventuele roepingsmotivatie en de mogelijke gevolgen daarvan voor hun werk en voor hun dagelijks leven, zoals tunnelvisie, zelfopoffering en extreme gedrevenheid.

- Onze bevindingen suggereren dat roeping het motivatieproces versterkt. Het significant negatief verband van roeping met emotionele 
uitputting suggereert dat roeping als een hulpbron op te vatten is. Een werkklimaat waarin de werknemer uitgedaagd wordt op een passende manier zijn passie voor het domein in te zetten, zal dan ook het welzijn van de werknemer en het belang van de organisatie kunnen dienen.

\section{Literatuur}

Ashmos, D.P. \& Duchon, D. (2000). Spirituality at work: A conceptualization and measure. Journal of Management Inquiry, 9, 134-145.

Bakker, A.B., Albrecht, S.L. \& Leiter, M.P. (2011). Key questions regarding work engagement. European Journal of Work and Organizational Psychology, 20, 4-28.

Bakker, A.B. \& Demerouti, E. (2006). The Job Demands-Resources Model: State of the art. Journal of Managerial Psychology, 22, 309-328.

Baruch,Y., Swartz, M., Sirkis, S., Mirecki, I. \& Barak, Y. (2013). Staff happiness and work satisfaction in a tertiary psychiatric centre. Occupational Medicine, 63, 442-444.

Bentler, P.M. \& Bonnett, D.G. (1980). Significance tests and goodness of fit in the analysis of covariance structures. Psychological Bulletin, 88, 588-606.

Bunderson, J.S. \& Thompson, J.A. (2009). The call of the wild: Zookeepers, callings, and the double-edged sword of deeply meaningful work. Administrative Science Quarterly, 54, 32-57.

Christian, M.S., Garza, A.S. \& Slaughter, J.E. (2011). Work engagement: A quantitative review and test of its relations with task and contextual performance. Personnel Psychology, 64, 89-136.

Cohen, J. (1988). Statistical power analysis for the behavioral sciences (2nd ed.). Hillsdale, NJ: Lawrence Erlbaum.

Conway, M.A. (2005). Memory and the self. Journal of Memory and Language, 53, 594-628.

Davidson, J.C. \& Caddell, D.P. (1994). Religion and the meaning of work. Journal for the Scientific Study of Religion, 33, 135-147.

De Jager Meezenbroek, E.C., Van der Berg, M., Tuytel, G., Visser, A. \& Garssen, B. (2006). Het meten van spiritualiteit als een universeel fenomeen: de ontwikkeling van de Spirituele Attitude en Interesse Lijst (SAIL). Psychosociale Oncologie, 14, 14-15.

De Jager Meezenbroek, E.C., Garssen, B., Van der Berg, M., Van Dierendonck, D., Visser, A. \& Schaufeli, W.B. (2012a). Measuring spirituality as a universal human experience: A review of spirituality questionnaires. Journal Religious Health, 51, 336-354.

De Jager Meezenbroek, E.C., Garssen, B., Van der Berg, M., Tuytel, G., Van Dierendonck, D., Visser, A. \& Schaufeli, W.B. (2012b). Measuring spirituality as a universal human experience: Development of the Spiritual Attitude and Involvement List (SAIL). Journal of Psychosocial Oncology, 30, 141-167.

Demerouti, E., Bakker, A.B., Nachreiner, F. \& Schaufeli, W.B. (2001). The job demandsresources model of burnout. Journal of Applied Psychology, 86, 499-512.

Dobrow, S. (2004, August). Extreme subjective career success: A new integrated view of having a calling. In Academy of Management Proceedings, 1, B1-B6. Academy of Management.

Dobrow, S.R. (draft: 2009). It's what you do and who you do it with: A longitudinal study of the sense of calling. Graduate School of Business Fordham University, New York. Gedown- 
load op 9 september, 2011 van www.bnet.fordham.edu/dobrow/docs/Antecedents. pdf.

Dobrow, S.R. \& Tosti-Kharas, J. (2011). Calling: The development of a scale measure. Personnel Psychology, 64, 1001-1049.

Duffy, R.D. \& Dik, B.J. (2013) Research on calling: What have we learned and where are we going? Journal of Vocational Behavior, 33, 428-436.

Eley, D., Eley, R., Bertello, M. \& Rogers-Clarck, C. (2012). Why did I become a nurse? Personality traits and reasons for entering nursing. Journal of Advanced Nursing, 68, 1546-1555.

Field, A. (2005). Discovering statistics using SPSS. London: Sage Publications.

Galea, M. (2014a). Assessing the incremental validity of spirituality in predicting nurses' burnout. Archive for the Psychology of Religion, 36, 118-136.

Galea, M. (2014b). The progressive impact of burnout on Maltese nurses. SOP Transactions on Psychology, 1, 1-12.

Golden, J., Piedmont, R.L., Ciarrocchi, J.W. \& Rodgerson, T. (2004). Spirituality and burnout: An incremental study. Journal of Psychology and Theology, 32, 115-125.

Hall, D.T. \& Chandler, D.E. (2005). Psychological success: When the career is a calling. Journal of Organizational Behavior, 26, 155-176.

Hackman, J.R. \& Oldham, G.R. (1976). Motivation through the design of work: Test of a theory. Organizational Behavior and Human Performance, 16, 250-279.

Hirsbrunner, L.E., Loeffler, D.N. \& Rompf, E.L. (2012). Spirituality and religiosity: Their effects on undergraduate social work career choice. Journal of Social Service Research, 38, 199-211.

Holland, J.M. \& Neimeyer, R.A. (2005). Reducing the risk of burnout in end-of-life care settings: The role of daily spiritual experiences and training. Palliative and Supportive Care, 3, 173-181.

Hu, L. \& Bentler, P.M. (1999). Cutoff criteria for fit indices in covariance structure analysis: Conventional versus new alternatives. Structural Equation Modeling, 6, 1-55.

Jöreskog, K.G. \& Sörbom, D. (1996). LISREL 8: User's Reference Guide. Lincolnwood, IL: Scientific Software International.

Kamin, M. \& Brinkman, A. (2008). Academic advising as purposeful work: Jobs, careers, and callings. NACADA Annual Conference, submission 357.

Karakas, F. (2009). Spirituality and performance in organisations: A literature review. Journal of Business Ethics, 94, 89-106.

Lips-Wiersma, M. (2002). The influence of spiritual 'meaning-making' on career behaviour. Journal of Management Development, 21, 497-520.

Maslach, C. \& Leiter, M. (1997). The truth about burnout: How organizations cause personal stress and what to do about it. San Fransisco, CA: Jossey-Bass.

Maslach, C., Schaufeli, W.B. \& Leiter, M.P. (2001). Job burn-out. Annual Review of Psychology, 52, 397-422.

May, D.R., Gilson, R.L. \& Harter, L.M. (2004). The psychological conditions of meaningfulness, safety and availability and the engagement of the human spirit at work. Journal of Occupational and Organizational Psychology, 77, 11-37.

Näring, G., Vlerick, P. \& Van de Ven, B. (2012). Emotion work and emotional exhaustion in teachers: The job and individual perspective. Educational Studies, 38, 63-72.

Rosenberg, M. (1989). Self-concept research: A historical overview. Social Forces, 68, 34-44.

Rosso, B.D., Dekas, K.H. \& Wrzesniewski, A. (2010). On the meaning of work: a theoretical integration and review. Research in Organizational Behavior, 30, 91-127. 
Rothmann, S. \& Hamukang'andu, L. (2013). Callings, work role fit, psychological meaningfulness and work engagement among teachers in Zambia. South African Journal of Education, 33, 1-16.

Schaufeli, W.B. \& Bakker, A.B. (2001). Werk en welbevinden: naar een positieve benadering in de Arbeids- en Gezondheidspsychologie. Gedrag \& Organisatie, 14, 229-253.

Schaufeli, W.B. \& Van Dierendonck, D. (2000). UBOS, Utrechtse Burn-out Schaal, handleiding. Amsterdam: Pearson Assessment and Information.

Schaufeli, W.B. \& Van Dierendonck, D. (2001). Utrechtse Burn-out Schaal (UBOS): psychodiagnostisch gereedschap. De Psycholoog, 1, 9-11.

Schaufeli, W.B. \& Van Rhenen, W. (2006). Over de rol van positieve en negatieve emoties bij het welbevinden van managers: een studie met de Job-related Affective Well-being Scale (JAWS). Gedrag \& Organisatie, 19, 323-344.

Schaufeli, W.B. \& Taris, T. (2013). Het Job Demands-Resources model: overzicht en kritische beschouwing. Gedrag \& Organisatie, 26, 182-204.

Sonnentag, S. (2011). Research on work engagement is well and alive. European Journal of Work and Organizational Psychology, 20, 29-38.

Thompson, J.A. \& Bunderson, J.S. (2003). Violations of principle: Ideological currency in the psychological contract. Academy of Management Review, 28, 571-586.

Van den Bossche, S.N.J., Hupkens, C.L.H., De Ree, S.J.M. \& Smulders, P.G.W. (2006). Nationale Enquête Arbeidsomstandigheden 2005. Hoofddorp:TNO.

Van den Broeck, A. (2013). Het Job Demands-Resources model: een motivationele analyse vanuit de Zelf-Determinatie Theorie. Gedrag \& Organisatie, 26, 449-466.

Van den Broeck, A., Van Ruysseveldt, J., Smulders, P. \& De Witte, H. (2011). Does an intrinsic work value orientation strengthen the impact of job resources? A perspective from the Job Demands-Resources Model. European Journal of Work and Organizational Psychology, 20, 581-609.

Van Ruysseveldt, J. (2006). Psychische vermoeidheid en plezier in het werk bij Vlaamse werknemers. Tijdschrift voor Arbeidsvraagstukken, 22, 328-343.

Van Veldhoven, M. \& Meijman, T.F. (1994). Het meten van psychosociale arbeidsbelasting met een vragenlijst: de vragenlijst beleving en beoordeling van de arbeid (VBBA). Amsterdam: NIA.

Weiss, J.W., Skelley, M.F., Haughey, J.C. \& Hall, D.T. (2004). Calling, new careers and spirituality: A reflective perspective for organizational leaders and professionals. In M.L. Pava \& P. Primeaux (Eds.), Spiritual intelligence at work: Meaning, metaphor, and morals (Research in Ethical Issues in Organizations, Volume 5) (pp. 175-220).

Wood, S., Stride, C., Threapleton, K., Wearn, E., Nolan, F., Osborn, D., Paul, M. \& Johnson, S. (2011). Demands, control, supportive relationships and well-being amongst British mental health workers. Social Psychiatry and Psychiatric Epidemiology, 46, 1055-1068.

Wrzesniewski, A. (2002). 'It's not just a job': Shifting meanings of work in the wake of 9/11. Journal of Management Inquiry, 11, 230-234.

Wrzesniewski, A., McCauley, C., Rozin, P. \& Schwartz, B. (1997). Jobs, careers, and callings: People's relations to their work. Journal of Research in Personality, 31, 21-33.

Ybema, J.F. \& Smulders, P. (2002). Emotionele belasting en de noodzaak tot het verbergen van emoties op het werk. Gedrag \& Organisatie, 15, 129-147.

\section{Workers with a calling: Blessed or in need in our care system?}

Coranne Steenkamp-Scheinhardt \& Gérard Näring, Gedrag \& Organisatie, volume 28, March 2015, nr. 1, pp. 27-45. 
People who feel they have a calling find their work meaningful. A calling leads to a heightened motivation for work and could therefore be related to less emotional exhaustion. The related concept of spirituality might also have an inverse relation with exhaustion. Calling might also moderate the relation between emotional demands and exhaustion.

We investigated these relationships in 235 employees working in a mental health institution. Spirituality overlapped only marginally with calling. There was a positive relationship between emotional demands and emotional exhaustion, and a negative relationship between calling and emotional exhaustion. Calling explained four percent of the variance in emotional exhaustion, but did not moderate the relation between emotional demands and emotional exhaustion. One aspect of spirituality, connectedness with the self, was also negatively related to emotional exhaustion. Persons with a calling are not protected in any special way from emotional demands, but suffer less from emotional exhaustion.

Key words: calling, emotional demands, emotional exhaustion, spirituality 